\title{
Myth therapy. Notes on collective traumatology
}

\author{
A. I. Brodsky
}

St. Petersburg State University, 7-9, Universitetskaya nab., St. Petersburg, 199034, Russian Federation

For citation: Brodsky A. I. Myth therapy. Notes on collective traumatology. Vestnik of Saint Petersburg University. Philosophy and Conflict Studies, 2021, vol. 37, issue 2, pp. 208-216.

https://doi.org/10.21638/spbu17.2021.202

The article analyzes the mechanisms for the formation of social myths, as well as their functions pertaining to collective trauma, and puts forward three theses. Firstly, the characteristics which turn text into myth depend not on its formal or essential features, but rather on its perception (how the audience interprets the meaning of its constituent statements). Anything can become a myth. Usually, a myth consists of depictions, statements, and explanations, that is, descriptive utterances. However, to understand a myth is to know the preconditions not for the truth and/or falsity of its constituent statements, but instead the implementation of certain rules of conduct. A myth is a description interpreted as a prescription. This approach makes it possible to understand how various scientific or philosophical theories, initially aiming to describe and explain the world, turn into myths determining the social behaviour of the masses. Secondly, a myth turns descriptions into prescriptions through "storytelling". A myth is a narrative which inevitably uses certain tropes essential for all narratives. The form of the narrative makes it possible to establish a pseudo-logical connection between various "elementary statements" capturing real or fictional events. Without such a connection, there is no value and, therefore, no normative perception of these events. Thirdly, the transformation of a description or explanation of a traumatic event into imperatives is the most important form of the therapy of collective consciousness. A description of a traumatic event turning into a call for action and construction of a new reality presents perhaps the only way to get rid of the destructive consequences of psychological trauma, both at the collective and individual level. Keywords: myth, imperative, norms, values, narrative, tropes, trauma, psychotherapy.

\section{Traumas and traumatologists}

More than 50 years ago, in his Tristes Tropiques and Structural Anthropology, Claude Lévi-Strauss drew a fairly convincing analogy between the practice of the shaman (sorcerer) and methods of psychoanalysis. The shaman and the psychoanalyst seek to soothe this or that pain by offering patients a certain system of representations and images in which the pain finds its place; thus, they can "reconcile" with the pain, and accept it as something understandable and explicable. "In both cases, the purpose is to bring to a conscious level conflicts and resistances which have remained unconscious, owing either to their repression by other psychological forces or... their own specific nature, which is not psychic but organic" [1, p.198]. Moreover, shamanism and psychoanalysis both succeed in approximately the same way, by "recreating a myth which the patient has to live or relive" [1,

* The research has been performed within the grant of the Russian Foundation for Basic Research no. 20-011-00124 "Transformation of the ethical culture under the influence of neurosciences".

(C) St. Petersburg State University, 2021 
p. 199]. It does not matter to what degree this myth corresponds to reality. However, as far as we can say on the basis of unconnected remarks, Lévi-Strauss himself was convinced that both shamanistic and psychoanalytic narratives have nothing to do with reality.

Of course, Lévi-Strauss noted that political ideology, or so-called "social myths", perform the same function in the case of "collective suffering" or collective trauma. Undoubtedly, the therapeutic role of myths in the life of society had been described long before Lévi-Strauss. Bronisław Malinowski wrote that people do not need myths constantly, but only in situations when they face something painful and, at the same time, incomprehensible. Following this view, Ernst Cassirer argued that a myth arises when people face an unexpected and dangerous situation. "This description of the role of magic and mythology in primitive society", he wrote, "applies equally well to highly advanced stages of man's political life. In desperate situations man will always have recourse to desperate means - and our present-day political myths have been such desperate means" [2, p. 279]. But the analogy with psychoanalysis allowed Lévi-Strauss not only to define the social role of myths, but also to clarify how myth-makers (shamans or political ideologists) solve their problems: they provide their patients with a language through which ineffable states can be directly expressed and without which it would be impossible to express them [1, p. 199-200].

At the turn of the $20^{\text {th }}$ century, when the study of so-called cultural or collective traumas became a separate branch of social and philosophical research, the very description of trauma came to be seen as a special form of psychotherapy. According to the "classical definition", "cultural trauma occurs when members of a collectivity feel they have been subjected to a horrendous event that leaves indelible marks upon their group consciousness, marking their memories forever and changing their future identity in fundamental and irrevocable ways" [3, p. 1]. In the works of the first "traumatologists", Katy Caruth [4] and Dominick LaCapra [5], cultural trauma was something "buried" in the collective subconscious, which constantly breaks out in the form of nightmares, phobias, obsessions, etc. Therefore, the purpose of therapy is to restore collective psychological health by eliminating social repression and finding a way to represent trauma in culture. Later on, however, for example in the famous collection "Cultural Trauma and Collective Identity" (2004), researchers began to argue that there are no traumatic events per se: an event becomes traumatic as a result of its conscious cultivation as a traumatic factor. This does not mean that there was no such event at all, but it can be perceived and experienced as a cultural trauma only if it has found its symbolic expression in culture, and has become an element of some kind of discourse or narrative [3]. In this sense, "cultural trauma" is similar, for example, to the "Oedipus complex" in Lévi-Strauss's interpretation: we are talking about a narrative which is constructed or reconstructed in the patient's memory - it does not matter whether or not this narrative bears any relation to reality.

Given the above, can it be argued that the therapeutic function of the myth is connected with the acquisition of some real or fictitious knowledge? Lévi-Strauss himself does not think so. In shamanistic or psychoanalytic practice, "conflicts and resistances are resolved, not because of the knowledge, real or alleged, which the sick woman progressively acquires of them, but because this knowledge makes possible a specific experience, in the course of which conflicts materialize in an order and on a level permitting their free development and leading to their resolution" [1, p. 198]. But what are these "experiences"? In the author's opinion, Lévi-Strauss does not have a clear answer to this question: at the 
very least, the text of Structural Anthropology needs some clarification. And this, in its turn, presupposes a refinement of our ideas about what constitutes myth and mythological thinking in general.

\section{The hidden imperative}

It is almost impossible to enumerate all the features with which researchers have tried to characterize myths and mythological thinking over the past two centuries. Among the essential attributes of myth were symbolism, metaphoricity, paralogicality, associativity, participativity, imaginativeness, etc. However, it has inevitably become clear that either certain properties are inherent not only to myths, or that not all myths have such properties. Very specific "paralogical" properties of mythological thinking can be described through classical logic, while modern logic can be constructed without the aid of some laws of classical logic. As a result, as early as the 1960s, in his paper on the psychology of myths, Alexander Piatigorsky had to acknowledge that there are no specific mythical texts. "The texts which are usually (that is, in everyday life, science, etc.) called mythical have very few differences from other texts which are not called mythical; in fact, there are no such differences" [6, p.39]. In the author's opinion, this means that anything can become a myth. This or that text becomes a myth not by virtue of its formal or substantive features, but due to its perception and the ways in which people interpret its constituent statements. The problem of myth is the problem of understanding.

In logical semantics, to understand the meaning of a statement means to know the conditions under which this statement can be considered true or false. Of course, this is true only for descriptive statements (that is, statements aiming to bring words into line with the world), but not for so-called prescriptive statements (declarations, imperatives, and promises aiming to bring the world into line with the words which refer to it). In the case of prescriptions, we speak not about the truth, but rather the feasibility of a statement - here to understand the meaning of statements means to know the conditions for their implementation. However, in practice, the logical and grammatical form of a statement does not always comply with its semantic interpretation (understanding): at times, descriptive statements are interpreted as imperatives. For example, the statement It is hot in this room can be understood as a request to open a window. It seems that in a text functioning as a myth there is the same discrepancy between grammar and semantics.

Usually, a myth consists of descriptions, statements and explanations, that is, it consists of descriptive statements. However, to understand myth is to know not the conditions for the truth and falsity of its constituent statements, but instead the conditions for the adherence to some code of conduct. At the very dawn of myth studies, Max Müller wrote: "By mythology I mean every case in which language, having become an independent force, influences the spirit instead of, in accordance with its initial purpose, being just the incarnation and manifestation of the spirit" (cit. ex: [7, p. 251]). In more recent times, the majority of researchers studying ancient myths (Ernst Cassirer, Mircea Eliade, Alexey F. Losev, Michael I. Steblin-Kamensky, Theocharis Ch. Kessidis et al) believed that in society myths perform not a cognitive, but rather a regulatory function. Of course, this does not mean that both ancient and modern myths are devoid of any elements of objective knowledge about the world. However, the purpose of myth is not to explain or describe the world, but to set a certain code of behaviour. 
In the discussion of the imperativeness or normativity of the myth, one should bear in mind the connection between the universally significant imperative, (that is, a norm) and value judgments. As Edmund Husserl rightly emphasized, "each normative proposition presupposes a certain sort of valuation or approval through which the concept of 'good' or 'bad' (a value or a disvalue) arises in connection with a certain class of objects" [8, p. 35]. More often than not, normative propositions can be transformed into value judgments, and vice versa. For example, as Rudolf Carnap noted, the difference between the statements Thou shalt not kill! and Murder is evil is purely stylistic [9, p. 25].

In the middle of the $20^{\text {th }}$ century, Roland Barthes analyzed the nature of myths from a linguistic point of view. According to Barthes, myth is a metalinguistic phenomenon: an object which in ordinary language is called a "sign" (the unity of the signifier and the signified), becomes just a signifier referring to another signified in the metalanguage. Therefore, the specific meaning of a word is supplemented with an additional (connotative) and, as a rule, ideological meaning. Thus, political rhetoric thrives on ideologically neutral words and thereby hides its true nature. In the author's opinion, the structure of mythological language described by Barthes is the very semiotic mechanism permitting social values and norms to be regarded as a description of the objective world.

However, it is important to emphasize that the connotative meaning is not necessarily false. Consider one of Barthes' examples referring to the 1950s, that is, to the period of the collapse of the French colonial system. The author sees the cover of a magazine with a picture of a young African man in French military uniform: looking at the waving French tricolour, he salutes. "Whether naively or not" - writes Barthes, - "I see very well what it signifies to me: that France is a great Empire, that all her sons, without any colour discrimination, faithfully serve under her flag, and that there is no better answer to the detractors of alleged colonialism than the zeal shown by this African in serving his so-called oppressors" [10, p. 115]. Probably, Barthes with his "left-wing views" considered the thesis about the "sons of the great Empire" to be false. But even assuming that the thesis was completely true at that time, and that all young African men were really happy to serve under French banner, the picture is still deceiving, since both the value and imperative nature of its message are hidden. Here, the myth is misleading, not because its message about reality is false, but due to its hidden ideological nature and attempts to misrepresent itself as objective information.

Thus, the most essential feature of mythological thinking is the identification of facts with norms. As a result, on the one hand, the myth does not reflect reality per se, but according to the social attitudes dominant in a specific historical period, and on the other hand, within the myth, social norms and values are something natural, indisputable, possessing the same universal and compulsory character as objective reality.

\section{Explicit narrativeness}

It goes without saying that hidden imperativeness per se cannot be the main, let alone the only, feature of the myth: otherwise, we would have to call "a myth" any declarative sentence involving a request or an order (e. g., the sentence It's hot in this room mentioned above). We should take into account the method allowing the hidden imperativeness to be achieved: namely, the story-telling, the narrative, where events are linked by a pseudo-logical connection and two consecutive events acquire the character of antecedent and consequent. 
We should emphasize that the narrativeness of a myth does not necessarily imply the immediate presence of a narrative. Such a narrative can be reconstructed by the interpreter of the myth, for example, in the case of the picture of a black soldier described by Barthes: the picture is a narrative - a story about an African man serving in the French army, which makes him happy because he participates in the common cause of the "great Empire".

At the end of the $20^{\text {th }}$ century, the concept of so-called "methodological narrativism" became very popular in the humanities. Methodological narrativism is the belief that the nature of certain theoretical disciplines depends on the methods of construction of a story about events, and the rhetorical devices used in the process. It was probably used most frequently in the description of the methods of historical science (H. White [11], F. Ankersmit [12]) and in the study of the foundations of ethics (A. McIntyre [13]). Later, "practical narrativism" (the use of narratives in psychotherapy) also emerged (M. White and D. Epton [14]). In the first case, we are talking about the fact that any historical description is constructed in accordance with the laws of literary genres and using certain tropes, and the question of the relations between this description and reality is highly ambiguous. In the second, we are saying that the foundations of our morals lie not in emotions and habits, but in the primary stories of a particular culture. This means that the answer to the main moral question What should I do? is identical to the answer to another question As a protagonist of which story can I imagine myself? In the third, we are saying that a person's life consists of many unrelated events; our self-identification and mental states depend on the events which we have chosen for the history of our life; psychotherapy aims to redesign these stories and lead a person to the creation of their most preferable life-story.

However, just like imperativeness, narrativeness by itself cannot be the hallmark of a myth: we cannot regard just any narrated story as a myth. That said, the unity of narrative and imperative is undoubtedly the main feature of myth. In social life, myth plays a therapeutic role similar to the role of narrative in the psychotherapeutic treatment of a "suffering" individual.

The combination of historical and ethical narrativism provides us quite a comprehensive vision of the nature of myth. "The substance (of myth)", as Lévi-Strauss notes, "does not lie in its style, its original music, or its syntax, but in the story which it tells" [1, p.210]. But do not forget that a myth is a story that sets up certain norms of behaviour. For example, Mircea Eliade, an authoritative expert on myths, argued that one of the most important characteristics of a myth is the creation of certain "typical models" for society using the example of an individual human life. Thus, a historical or mythological character turns into an archetype [15].

It is no coincidence that today historical science is the most important source of myths. This inevitably raises the question as to whether history can be a science (that is, it can tell us something about facts which can be verified). Contrary to the popular opinion that history is not a science, but "politics projected into the past" or something along those lines, this author will insist that history can of course be a science, although its data will surely never enjoy the same degree of reliability and verifiability as the data of the natural sciences. Statements about certain historical events are always controversial, but, unlike mythological statements, one can still argue about them, citing completely rational arguments, proofs, or refutations. But all this only holds true for isolated, "elementary" statements of fact: when historical science begins to look for the necessary (logical) internal connection between these facts, it turns into mythology. As Ludwig 
Wittgenstein stated at the beginning of the $20^{\text {th }}$ century: "There is no possible way of making an inference from the existence of one situation to the existence of another, entirely different situation. There is no causal nexus to justify such an inference. We cannot infer the events of the future from those of the present. Superstition is nothing but belief in the causal nexus" [16, p.47].

In fact, an isolated historical event has little effect on subsequent events, perhaps not at all. We can connect events with each other only with the help of certain rhetorical devices or tropes. For example, the more metaphorical the reproduction of an event is, the more varied "necessary" consequences we will be able to derive from it. However, only "events connected with each other" allow the historian to interpret facts in a value-based or normative way, and turn an historical description into some kind of "lesson". "We should draw the lessons from history!" - a trivial and, at the same time, completely ridiculous statement. In fact, history does not teach us any "lessons", if only because any lesson, any moral and any politics, can be drawn from any "story". Thus, history as an internally interconnected sequence of events from which some "lesson" can be drawn is always either myth or "fiction".

\section{Cura te ipsum!}

What is the essence of the "therapeutic experiences" provided by real or fictitious mythological knowledge? In short, it is freedom from decision-making. In this sense, myths are fundamentally different from morals and law.

We can call an action moral if it is the result of a conscious and free choice. Such an understanding of morality means not only that an involuntary action is not moral, but also that, at the moment when a person makes a decision, there is no necessity excluding other possible ways of behaving. The desire to find some true basis for our moral decisions, which would exclude alternative forms of behaviour, is both unfeasible and incompatible with the very essence of morality. As Karl Popper rightly noted, "if it could be achieved, it would destroy all personal responsibility and therefore all ethics” [17, p. 207].

All this is also applicable to law. In the $20^{\text {th }}$ century, the famous logician and lawyer Chaïm Perelman noted that if legal norms had not been arbitrarily established rules but true judgments, we would not have needed any judicial authorities to make decisions on the legality or otherwise of certain actions. "What is a question of decision cannot be a question of truth. One must yield to truth; there is no room for deciding. I do not decide that two plus two make four or that Paris is the capital of France" [18, p. 172].

The theoretician of so-called "Revolutionary syndicalism", Georges Sorel, one of the first apologists for social myths, gave probably the most accurate description of their practical and therapeutic role. According to Sorel, myth awakens the "will to action", generates the élan vital, and therefore resists inertia, passivity, depression, selfishness, and phobias. Thus, myths have nothing to do either with morals and law or with ideologies and utopias. As a result of rational thinking, ideologies and utopias can always be subject to rational criticism, while any critical assessment of myth is impossible. "A myth cannot be refuted since it is, fundamentally, identical to the convictions of a group, being the expression of these convictions in the language of movement... A utopia, on the other hand, can be discussed like any other social constitution... it is possible to refute it by showing that the economic system on which it has been made to rest is incompatible with the necessary conditions of modern production" [19, p.29]. Here we should note that Sorel, who con- 
sidered himself a Marxist, became one of the "spiritual fathers" of fascism (that, at least, was Benito Mussolini's opinion).

It is obvious that mythological thinking is a therapy which itself needs treatment. Mythological thinking is akin to drug addiction: of course, it can alleviate all manner of suffering and pain, but, in its turn, it also causes a lot of other problems and, in some cases, even death. But is it possible to rid people of myths, and if so, by what means?

The scientific disciplines, empirical, logical, and mathematical, reign over a completely different plane of human existence and do not influence mythological thinking. There have been many famous scientists with the most absurd mythological beliefs about some areas of social and cultural life.

Monotheistic religions have a more pronounced anti-mythological potential. Religion stands out from mythology by virtue of its exegesis, that is, the allegorical or symbolical interpretation of its images and narratives. On the other hand, without exegesis religion becomes just a myth: a mixture of divine and earthly elements, the deification of some worldly forces, the worship of creation but not of the Creator - the Bible calls it idolatry. Nevertheless, anti-mythological religiosity is something extremely rare. It was practised only by certain ancient prophets, several enlightened medieval scholastics, and a number of modern intellectuals. On the whole, it is abundantly clear that if your aim is to promote mythological thinking, then mass religiosity works like nothing else.

Finally, throughout all its history philosophy has been well renowned for its ability to demythologize. By subjecting cultural norms and values to critical reflection and trying to find their first causes, philosophy challenges them and makes them the subject of rational discussion. However, having established the path from myth to logos, philosophy can always return to myth. Even Plato himself, who reproached mythologists and poets for a false image of reality, and expelled them from his ideal state, created new myths. He believed that such a symbolic, non-philosophical expression of ideas is very useful for practical purposes, for example, in the process of the raising and training of the guards in that same ideal state. Moreover, when the philosophy of modernity, with its critical attitude to various "idols" of the mind, became the spiritual basis for the revolution, the enlightened belief in reason turned into the worship of the Supreme Being. Attempts to put philosophical ideals into practice have always resulted in the mythologization of philosophy.

The fact that philosophy, like science, is always open to rational criticism, while mass movements are usually inspired by ideas (however illusory they may be, they are considered indisputable) is equally important for the explanation of the mythologization of philosophical knowledge. It is no coincidence that, when exploring the role of beliefs in history, Joseph Renan concluded: "The future lies in the hands of those who are not disillusioned" (cit. ex: [19, p. 24]).

Thus, there is no cure for mythological thinking - it is impossible. Therefore, we should not struggle with myths but "work with them correctly" as with any other means of psychotherapy. They should be adequate for the social goals of modernity and preferential value attitudes.

\section{References}

1. Lévi-Strauss, C. (1963), Structural Anthropology, transl. by Jacobson, C. and Brooke, G., New York: Schoepf, Basic Books.

2. Cassirer, E. (1946), The Myth of the State, New Haven: Yale University Press. 
3. Alexander, J. C., Eyerman, R., Giesen, B., Smelser, N. J. and Sztompka, P. (2004), Cultural Trauma and Collective Identity, Berkeley, Los Angeles, London: University of California Press.

4. Caruth, C. (1995), Trauma: Explorations in Memory, Baltimore: Johns Hopkins University Press.

5. LaCapra, D. (1994), Representing the Holocaust: History, Theory, Trauma, New York: Ithaca, Cornell University Press.

6. Piatigorskij, A.M. (1965), Some general remarks about mythology from the point of view of a psychologist, Uchennye zapiski Tartuskogo universiteta, iss. 181, pp. 38-48. (In Russian).

7. Potebnia, A. A. (1989), Word and myth, Moscow: Pravda Publ. (In Russian).

8. Husserl, E. (2002), Logical Investigations. Vol.I. Prolegomena to pure logic, transl. by Findlay, J. N., London and New York: Routledge Publ.

9. Carnap, R. (1937), The logical syntax of language, transl. by Smeaton, A., New York: Harcourt, Brace and Co., London: Kegan Paul, Trench, Trubner and Co.

10. Barthes, R. (1972), Mythologies, transl. by Lavers, A., New York: Farrar, Straus and Giroux Publ.

11. White, H. (1975), Metahistory, The Historical Imagination in Nineteenth-Century Europe, Baltimore: Johns Hopkins University Press.

12. Ankersmit, F. R. (1994), History and tropology. The rise and fall of metaphor, Berkeley: University of California Press. Press.

13. MacIntyre, A. (1985), After Virtue: A Study in Moral Theory, Chicago: University of Notre Dame

14. White, M., Epston, D. (1990), Narrative Means to Therapeutic Ends, New York: W. W. Norton \& Co.

15. Eliade, M. (1957), Mythes, rêves et mystères, Paris: Gallimard.

16. Wittgenstein, L. (2001), Tractatus Logico-Philosophicus, transl. by Pears, D. F. and McGuinness, B. F., London and New York: Routledge.

17. Popper, K. R. (1945), The open society and its enemies, vol. 1: The spell of Plato, London: Routledge.

18. Perelman, Ch. (1980), Justice, law and argument, Boston: Springer Publ., London: Dordrecht.

19. Sorel, G. (1999), Reflections on Violence, ed. by Jennings, J., Cambridge: Cambridge University Press.

Received: September 8, 2020

Accepted: March 10, 2021

Author's information:

Alexander I.Brodsky — Dr. Sci. In Philosophy, Professor; abrodsky59@mail.ru

\title{
Мифотерапия. Заметки по коллективной травматологии
}

\author{
А. И. Бродский \\ Санкт-Петербургский государственный университет, \\ Российская Федерация, 199034, Санкт-Петербург, Университетская наб., 7-9
}

Для цитирования: Brodsky A. I. Myth therapy. Notes on collective traumatology // Вестник СанктПетербургского университета. Философия и конфликтология. 2021. Т. 37. Вып. 2. С. 208-216. https://doi.org/10.21638/spbu17.2021.202

В статье анализируются механизмы формирования социальных мифов и функции, которые эти мифы выполняют по отношению к коллективным травмам. Статья включает в себя три тезиса. Первый тезис состоит в утверждении, что то, что делает тот или иной текст мифом, зависит не от его формальных или содержательных особенностей, а от того, как это текст воспринимается людьми, как понимается значение составляющих его высказываний. Мифом может стать все что угодно. Миф обычно состоит из описаний, утверждений и объяснений, т.е. из высказываний дескриптивного характера.

* Исследование выполнено в рамках гранта Российского фонда фундаментальных исследований № 20-011-00124 «Трансформация нравственной культуры под влиянием нейронаук». 
Однако понимание мифа предполагает знание не условий истинности и ложности составляющих его высказываний, а условий выполнения определенных требований к поведению. Миф - это дескрипция, интерпретируемая как прескрипция. Подобный подход позволяет понять, как различные научные или философские теории, задача которых изначально состояла в описании и объяснении мира, превращаются в мифы, определяющие социальное поведение масс. Второй тезис состоит в том, что превращение дескрипций в прескрипции достигается мифом благодаря "рассказыванию историй». Миф - это всегда нарратив, и он всегда использует определенные тропы, характерные для нарративов. Форма нарратива позволяет установить между различными «атомарными высказываниями», фиксирующими реальные или вымышленные события, псевдологическую связь, без которой невозможно ценностное и, следовательно, нормативное восприятие этих событий. Третий тезис состоит в утверждении, что превращение описания или объяснения травматического события в императивы является важнейшей формой терапии коллективного сознания. Описание травмирующего события, которое превращается в призыв к действию и конструированию новой реальности, является едва ли не единственным способом избавиться от деструктивных последствий психологической травмы как на коллективном, так и на индивидуальном уровне.

Ключевые слова: миф, императив, нормы, ценности, нарратив, тропы, травма, психотерапия.

Статья поступила в редакцию 8 сентября 2020 г.; рекомендована в печать 10 марта 2021 г.

Контактная информация:

Бродский Александр Иосифович - д-р филос. наук, проф.; abrodsky59@mail.ru 